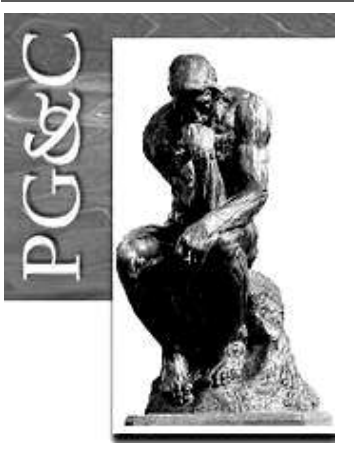

\title{
TRANSFORMAÇÃO DIGITAL E GESTÃO DO CONHECIMENTO
} comunicação nas organizações vem possibilitando mudanças radicais em suas estruturas e processos internos, na cadeia de suprimentos, bem como oportunizando novos negócios e empresas onde a criação de conhecimento, colaboração e inovação fazem parte do cerne da economia do conhecimento.

Empresas nativas digitais surgem com práticas de Gestão do Conhecimento (GC) em sua essência, possibilitando o desenvolvimento de questões como: é possível aprender com as empresas nativas digitais a incorporar a GC no dia a dia das organizações tradicionais? Existe uma nova GC surgindo na Era Digital? E, quais os impactos da transformação digital na GC?

Neste sentido, o Congresso Brasileiro de Gestão do Conhecimento (KM Brasil), organizado pela Sociedade Brasileira de Gestão do Conhecimento (SBGC), chegou a 15a edição com o tema principal "Transformação Digital e Gestão do Conhecimento".

Em 2020, o KM Brasil aprovou 67 artigos dos quais selecionamos onze trabalhos para esta edição especial da revista Perspectivas em Gestão \& Conhecimento (PG\&C). As submissões foram realizadas subdivididas em nove trilhas temáticas, a saber:

1. Inovação e aspectos estratégicos da GC

2. Sustentabilidade nos negócios e GC

3. Ativos intangíveis, capital intelectual e humano relacionados à $\mathrm{GC}$

4. Redes sociais, ensino e aprendizagem com foco em GC

5. Práticas de Gestão do Conhecimento e Tecnologias de Gestão do Conhecimento

6. Novos saberes e abordagens interdisciplinares relacionados à GC

7. A transformação digital e os desafios para a GC

8. Cidades Inteligentes e Sustentáveis

9. Tecnologia da Informação Inteligente e Gestão do Conhecimento

Os textos aqui apresentados nesta edição especial da PG\&C são oriundos de pesquisas acadêmicas teóricas e práticas em organizações públicas e privadas, as quais esperamos que sirvam de inspiração para reflexões, provocações e contribuições ao campo científico da Gestão do Conhecimento.

Parabenizo os autores e agradeço aos membros e revisores do Conselho Científico da SBGC, bem como a Professora Luciana Ferreira da Costa e o Professor Jorge de Oliveira Gomes por mais esta edição especial da PG\&C.

São Paulo, Brasil, 22 de fevereiro de 2021.

Fábio Câmara Araújo de Carvalho

Doutor em Administração pela Escola Superior de Propaganda e Marketing (ESPM)

Professor da ESPM

Vice-presidente e coordenador do Conselho Científico da SBGC

E-mail: $\underline{\text { fcarvalho@espm.br }}$ 